\title{
Pengaruh Strategi Inovasi Terhadap Keunggulan Bersaing di Industri Kreatif (Studi Kasus UMKM Bidang Kerajinan Tangan di Kota Bandung)
}

\author{
Tintin Suhaeni ${ }^{1 *}$ \\ ${ }^{1}$ Jurusan Administrasi Niaga, Politeknik Negeri Bandung, Indonesia
}

\begin{abstract}
:
Creative industry is one of sector that has rapid development in Indonesia, especially in Bandung. The part of this sector that tends to decrease every year or have smallest development level is Handycrafts. Although the number of businessman in this part is less than in food and beverage part, the competition between them is also fierce. The businessman should be the one who can decide the proper competitive strategy to survive in this competition. The other way to do to win the competition is applying innovation strategy towards the product so that it can be different from our competitor products and attract more customers. This research determined the relationship between innovation strategy and competitive advantage in the UKM handycraft business in Bandung. Linear regression will be used for determine this relationship.
\end{abstract}

Keywords: competitive strategy, innovation, linear regression, UKM

\begin{abstract}
Abstrak:
Industri kreatif adalah salah satu sektor yang memiliki perkembangan pesat di Indonesia, khususnya di Bandung. Bagian dari sektor ini yang cenderung menurun setiap tahun atau memiliki tingkat pengembangan terkecil adalah kerajinan tangan. Meskipun jumlah pengusaha di bagian ini lebih sedikit daripada di bagian makanan dan minuman, persaingan di antara mereka juga sengit. Pengusaha harus menjadi orang yang dapat memutuskan strategi bersaing yang tepat untuk bertahan dalam kompetisi ini. Cara lain yang dilakukan untuk memenangkan persaingan adalah menerapkan strategi inovasi terhadap produk sehingga dapat berbeda dari produk pesaing kami dan menarik lebih banyak pelanggan. Penelitian ini menentukan hubungan antara strategi inovasi dan keunggulan kompetitif dalam bisnis kerajinan tangan UKM di Bandung. Regresi linear akan digunakan untuk menentukan hubungan ini.
\end{abstract}

Kata Kunci: strategi bersaing, inovasi, regresi linier, UKM

*Email korespondensi:

Tintin Suhaeni

tintin.suhaeni@polban.ac.id

\section{PENDAHULUAN}

\section{Latar Belakang}

Industri kreatif merupakan salah satu bidang usaha yang sedang banyak diminati 
oleh masyarakat Indonesia saat ini. Kementrian Perdagangan Indonesia mendefinisikan industri kreatif sebagai industri yang bersumber dari pemanfaatan kreativitas, keterampilan dan bakat individu untuk menciptakan kesejahteraan serta lapangan pekerjaan dengan mengeksploitasi daya kreasi dan daya cipta individu tersebut. Bidang usaha ini banyak diminati karena memiliki pasar dan keuntungan yang cukup besar. Berdasarkan data Kementrian Perindustrian RI tahun 2016, industri ini telah menyumbang $\mathrm{Rp}$ 642.000.000.000.000,00 atau 7,05\% dari total produk domestik bruto (PDB) Indonesia.

Usaha mikro kecil menengah (UMKM) termasuk pihak yang terlibat dalam industri kreatif. Berdasarkan lembaga pengembangan perbankan Indonesia dan Bank Indonesia (BI) mengidentifikasi karakteristik usaha kecil adalah jenis komoditi yang dihasilkan sudah tetap, lokasi tidak berpindah-pindah, sudah melakukan administrasi keuangan, memiliki izin usaha, dan memiliki sumber daya yang berpengalaman dalam berwirausaha. Sedangkan usaha menengah memiliki kondisi organisasi yang lebih baik karena sudah memiliki organisasi perburuhan, menerapkan sistem akuntansi dengan baik, dan memiliki akses pada sumber dana perbankan.

Kota Bandung menjadi salah satu kota di Indonesia yang memiliki perkembangan cukup pesat bagi UKM di bidang industri kreatif. Menurut data dari Dinas KUMKM dan Perindag Kota Bandung pada tahun 2016, jumlah UKM di kota Bandung menjadi 5.365 usaha atau meningkat sebanyak $21,323 \%$ dari tahun 2010. Banyakya UKM di Kota Bandung membuat para pelaku usaha harus memikirkan strategi terbaik yang akan diterapkan pada usahanya agar mampu bertahan dari para pesaingnya.

Strategi bersaing adalah salah satu strategi yang dapat digunakan oleh para pelaku usaha dalam menghadapi persaingan. Strategi ini secara umum dapat diartikan sebagai sebuah proses dimana perusahaan membangun dan mengembangkan berbagai sumber daya stratejik yang memiliki potensi untuk menghasilkan keunggulan bersaing. Keunggulan tersebut memiliki dua peran, yaitu sebagai alat untuk menghasilkan kinerja dan sebagai alat untuk menetralisir asset dan kompetensi bersaing yang dimiliki oleh pihak pesaing.

Salah satu hal yang dapat dilakukan oleh para pelaku usaha UKM adalah dengan melakukan inovasi. Charan et al. (2008) menyatakan bahwa inovasi tidak hanya mendorong pertumbuhan keuntungan, tetapi juga meningkatkan berbagai kamampuan seperti kemampuan untuk mamasuki pasar dan menarik pelanggan. Strategi inovasi ini nampaknya masih belum diterapkan di UKM dengan tipe bisnis kerajinan tangan. Hal ini dapat terlihat dari jumlah UKM di bidang tersebut yang menurun setiap tahunnya, berbeda cukup jauh dengan tipe usaha makanan, minuman, dan fashion. Berdasarkan data dinas KUMKM dan Perindag Kota Bandung tecatat banyaknya pelaku UKM di tipe industry kreatif hanya meningkat sebanyak 170 dari tahun 2010 hingga 2017, sedangkan UKM dengan tipe makanan dan minuman serta fashion berada diangka 676 dan 329.

Beberapa penelitian menyatakan adanya hubungan anatara keunggulan bersaing dan inovasi. Martim de Conto et al. (2016), pelaku usaha yang memiliki keunggulan bersaing dan harus memiliki kemampuan berpikir kreatif dan inovatif. 
Hasil penelitian mendukung hasil penelitian sebelumnya, bahwa perusahaan tanpa kreativitas dan inovasi tidak akan bersaing dan bertahan di era persaingan yang semakin tajam (Larsen et al., 2007). Selain itu, Gronhaug dan Kaufmann dalam Han et al. (1998) menyatakan bahwa inovasi menjadi semakin penting sebagai sarana bertahan, bukan hanya pertumbuhan dalam menghadapi ketidakpastian lingkungan dan kondisi persaingan bisnis yang semakin meningkat. Studi yang dilakukan oleh Hurley et al. (1998) juga menyimpulkan bahwa perusahaan dengan kemampuan berinovasi tinggi akan lebih berhasil dalam merespon lingkungannya dan mengembangkan kemampuan baru yang menyebabkan keunggulan kompetitif dan kinerja yang superior. Hasil penelitian Muthami Kising et al. (2016) juga menunjukkan bahwa inovasi organisasi, inovasi produk, inovasi administrasi, dan inovasi proses memainkan peran penting secara berkelanjutan keunggulan kompetitif universitas di Kenya.

Berdasarkan beberapa penelitian di atas, dapat disimpulkan inovasi memiliki pengaruh terhadap keunggulan bersaing. Maka perlu dilakukan penelitian untuk mengetahui pengaruh strategi inovasi terhadap keunggulan bersaing untuk kasus usaha kecil dan menengah di bidang industri kreatif kerajinan tangan di kota Bandung.

\section{TINJAUAN PUSTAKA}

\section{Inovasi}

Inti dari sebuah kegiatan inovasi adalah bagaimana melakukan sebuah kegiatan yang bisa menaingkatkan nilai (added value) dan keunggulan dari kondisi saat ini. Cara-cara yang bisa dilakukan antara lain dengan cara menciptakan pengembangan yang berbeda dari produk atau jasa yang sudah ada di pasar saat ini, atau menciptakan produk atau jasa yang sekiranya dapat menciptakan potensi pasar yang baru (Datta, et.al,2011 dalam (Dhewanto et al., 2015).

\section{Pengertian Inovasi}

Thornhill (2006) dalam Rosli et al. (2013) mendefinisikan inovasi sebagai suatu proses penciptaan gagasan, pengembangan dari suatu keterbaruan, dan pengenalan suatu produk baru, proses atau pelayanan kepada masyarakat. Selain itu, Pearce et al. (2013) juga berpendapat inovasi merupakan komersialisasi awal penemuan dengan menghasilkan dan menjual suatu produk, jasa, atau proses baru. Menurut Sukmadi (2016), inovasi berarti suatu ide, produk, informasi teknologi, kelembagaan, perilaku, nilai-nilai, dan praktik-praktik baru yang belum banyak diketahui, diterima, dan digunakan atau diterapkan oleh sebagian besar warga masyarakat dalam suatu lokalitas tertentu, yang dapat digunakan atau mendorong terjadinya perubahan-perubahan di segala aspek kehidupan masyarakat.

\section{Jenis-Jenis Inovasi}

Roberts et al. (2003) menyatakan inovasi dapat dilakukan dengan dua cara, yaitu secara radikal dan incremental. Inovasi secara radikal berarti menciptakan produk yang benar-benar baru, yang umumnya dilakukan dengan adanya dorongan teknologi (technology push), sedangkan inovasi yang dilakukan secara incremental dilakukan melalui perbaikan atau menyempurnakan produk yang sudah ada pada waktu sebelumnya, yang biasanya dikaitkan dengan tarikan pasar (market pull). Pendapat yang sama dikemukakan oleh Pearce et al. (2013), bahwa jenis inovasi terdiri dari inovasi incremental dan 
inovasi terobosan. Jenis inovasi terobosan ini sama dengan inovasi radikal, hanya istilahnya saja yang berbeda.

Sementara itu, Hendro (2011) menerangkan jenis-jenis inovasi terdiri dari inovasi produk, inovasi pemasaran, inovasi proses, inovasi teknikal, dan inovasi administrasi. Inovasi produk menjelaskan mengenai produk yakni bagaimana isi produk tersebut, seperti apa rasanya, kualitasnya, dan yang lainnya. Inovasi produk juga melihat bagaimana kemasan dari produk tersebut, seperti apa pembungkusnya, tulisan, warna, sistem untuk membuka tutup, bentuknya, dan lain sebagainya. Selanjutnya, inovasi pemasaran membahas mengenai bagaimana cara seorang pengusaha dalam menjual produknya, seperti bagaimana ia mendistribusikannya, memasarkannya, mengiklankannya, dan bagaimana cara menciptakan permintaan. Kemudian selanjutnya adalah inovasi proses. Dapat dilihat dari bagaimana proses pengusaha menciptakan produk, proses produksi, proses teknologi pengemasannya, riset dan pengembangan, menciptakan mesin baru, dan lain lain. Inovasi teknikal terdiri dari teknik desain, teknik pengawasan, dan teknik pengerjaannya. Yang terakhir, inovasi administrasi berisi mengenai bagaimana seorang pengusaha menyimpan data, membuat dan mengumpulkan data.

$$
\text { Oslo OECD (2005) juga }
$$

mengidentifikasi dan membedakan empat jenis utama dari inovasi, yaitu : produk, proses, pemasaran, dan organisasi. Dimana inovasi pada produk dan proses terkait erat dengan inovasi teknologi. Sementara cakupan inovasi pada pemasaran dan organisasi lebih luas lagi, berhubungan dengan berbagai inovasi yang tidak berbasis teknologi. Gambar 1 memperlihatkan struktur ke empat jenis inovasi tersebut.

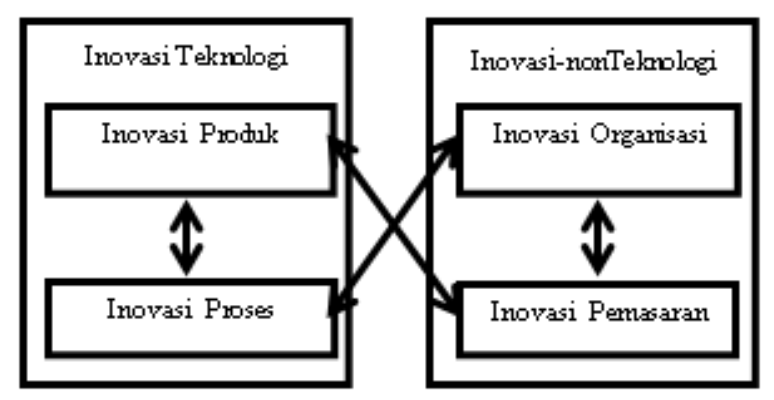

Gambar 1 Jenis-Jenis Inovasi Menurut Oslo Manual (2005)

\section{Strategi Inovasi}

Hittmár et al. (2014) mendefinisikan strategi inovasi sebagai suatu alat dasar yang menentukan arah inovasi bisnis berdasarkan strategi bisnis dan tujuan strategis. Kazinguvu (2016) berpendapat bahwa inovasi strategis adalah ciptaan dari strategi pertumbuhan, teknologi baru, pelayanan baru, cara baru dalam melakukan sesuatu atau suatu bisnis model yang merubah permainan dan menghasilkan nilai baru yang signifikan untuk konsumen, dan pelanggan.

Strategi inovasi dibutuhkan dalam UMKM karena dalam banyak industri, akan semakin berisiko jika perusahaan tidak berinovasi. Baik konsumen maupun industri telah mengalami perubahan dan perbaikan berkala terhadap produk yang ditawarkan. Akibatnya, beberapa perusahaan merasa beruntung bisa melakukan inovasi strategi (Kazinguvu, 2016). Strategi inovasi juga membantu bisnis menemukan tantangan baru bagi perkembangan dan pertumbuhan mereka. Strategi inovasi merupakan konsep manajemen, terdiri dari banyak kegiatan internal dan eksternal yang meningkatkan potensi inovasi bisnis. Hal ini diperlukan untuk menekankan pentingnya dan peranan yang mempengaruhi pembentukan strategi inovasi. Peranan tersebut berasal dari 
karyawan bisnis, manajer, dan juga pelanggan (Hittmár et al., 2014).

\section{Dimensi Inovasi}

Inovasi merupakan suatu konsep multi dimensional yang terdiri dari empat dimensi (Zahra \& Das, 1939; Ellitan dan Anatan, 2009; Perwiranegara, 2015). Konsep mutidimensi inovasi di atas akan menghasilkan pengukuran yang lebih baik dibandingkan dengan hanya pada satu dimensi saja (Hadjimanolis et al., 2000). Zahra et al. (1993) dalam Anatan et al. (2009) menyatakan empat dimensi inovasi terdiri dari orientasi kepemimpinan, inovasi 'followership', sumber inovasi, dan tingkat investasi.

Orientasi kepemimpinan pasar menurut Maidique \& Patch (1988) dalam Perwiranegara (2015) menunjukkan bahwa kepemimpinan pasar dapat dilihat dari orientasi perusahaan dalam rangka memasuki pasar, yaitu (Alstermark et al., 2006): Perusahaan yang mengadopsi a firstto-market biasanya menggunakan inovasi produk dan proses sebagai ujung tombak operasionalnya yang bertujuan untuk melestarikan dan meningkatkan pangsa pasar. Second-to-market atau strategi follower cepat adalah strategi dimana perusahaan masuk awal dalam tahap pertumbuhan siklus hidup produk dan dengan cepat meniru inovasi perusahaan perintis. Perusahaan yang mengadopsi second-to-market biasanya memonitor inovasi-inovasi yang diperkenalkan oleh pesaing-pesaing yang terkenal, dan secara cepat meniru inovasi tersebut.

Tipe inovasi terbagi menjadi dua, yaitu inovasi produk dan inovasi proses (Ellitan \& Anatan, 2009). Langley et al. (2005) dalam Rosli et al. (2013) mendefinisikan inovasi produk sebagai suatu kreasi suatu produk baru dari bahan baku baru (benar-benar produk baru) atau pembaruan dari produk yang telah ada sebelumnya untuk memenuhi kepuasan pelanggan (versi perbaikan dari produk sebelumnya). Briones (2014) juga menyebutkan bahwa inovasi produk bukan hanya sekedar menemukan hal atau produk yang baru, namun hal baru tersebut harus berpotongan dengan added value atau nilai tambah dalam barang. Jadi jika tercipta produk baru atau penemuam baru yang tidak menawarkan nilai tambah di dalamnya, maka belum bisa disebut inovasi produk. Value merupakan ukuran yang terdiri dari dua aspek. Aspek yang pertama adalah keinginan atau desirability, dan aspek yang kedua adalah functionality. menurut OECD Oslo Manual (2010), sebuah proses inovasi adalah implementasi yang baru atau secara signifikan ditingkatkan produksi atau metode pengiriman. Ini termasuk perubahan teknik, peralatan yang signifikan dan / atau perangkat lunak. Inovasi proses dapat dimaksudkan untuk mengurangi biaya produksi unit atau pengiriman, untuk meningkatkan kualitas, atau menghasilkan atau mengirimkan produk baru atau meningkat secara signifikan. Menurut Elitan \& Anatan (2009) inovasi proses menekankan pada metode-metode baru dalam pengoperasian dengan cara membuat teknologi baru atau mengembangkan teknologi yang telah ada.

Dimensi ketiga yaitu sumber inovasi yang menjelaskan pelaksanaan aktivitas inovasi, apakah ide inovasi berasal dari internal perusahaan, eksternal perusahaan atau keduanya (Ellitan \& Anatan, 2009). Sumber inovasi internal memliki makna bahwa perusahaan mempercayakan untuk melakukan inovasi baik pada proses atau produk pada usaha bagian riset dan 
pengembangan. Sedangkan sumber inovasi eksternal memliki makna perusahaan akan melakukan inovasi dengan cara membeli, persetujuan lisensi, akuisisi perusahaan lain atau kerjasama dengan suplier, pelanggan atau perusahaan lain. Menurut Hendro (2011), ada beberapa sumber yang bisa mendorong terjadinya inovasi. Sumber yang pertama adalah perbedaan (gap) antara permintaan (demand) dan penawaran (supply). Dalam sebuah wilayah/negara yang memiliki kebudayaan tertentu, biasanya penawaran produk yang tidak sesuai dengan permintaann yang ada akan memunculkan sebuah inovasi. Kemudian sumber selanjunya adalah penciptaan permintaan karena kecenderungan (trend). Adanya kecenderungan pola hidup masyarakat Indonesia yang menyukai produk yang instan, maka munculah produkproduk lain yang mengikuti tren tersebut. Sumber yang lainnya adalah perubahan (change). Perubahan-perubahan itu seperti perubahan ekonomi, perubahan teknologi, perubahan sosial, dan lain lain. Selanjutnya adalah masalah yang belum terpecahkan dalam jangka waktu lama. Terkadang masalah dalam jangka waktu yang lama belum tentu dapat terselesaikan dengan cara pemecahan masalah kreatif. Sumber inovasi yang terakhir adalah inovasi yang ditujukan untuk mengganti inovasi produknya sendiri. Hampir sebagian besar industri berteknologi menggunakan prinsip ini agar produknya bisa diganti dengan produk yang baru diluncurkan sehingga masih bisa menjadi pimpinan pasar.

Dimensi yang terakhir adalah tingkat investasi mencakup investasi baik dalam hal investasi keuangan, teknologi maupun investasi sumber daya manusia. Investasi keuangan meliputi pengeluaran untuk proyek riset dan pengembangan, dan pembelian satu inovasi pada produk yang telah dikembangkan di tempat lain. Investasi teknologi adalah pengeluaran untuk peralatan, infrastruktur, fasilitas dasar yang dibutuhkan untuk melakukan inovasi. Investasi di bidang sumber daya manusia termasuk diantaranya gaji, pelatihan, dan biaya-biaya lain yang berhubungan dengan pengembangan staf. (Ellitan \& Anatan, 2009).

\section{Faktor Pendukung Keberhasilan Inovasi}

Quinn dalam Hendro (2011) menjelaskan faktor-faktor pendukung untuk tercapainya keberhasilan penerapan kemampuan inovatif yang pertama adalah harus berorientasi pasar. Banyak inovasi yang dilakukan hanya sekedar memecahkan masalah kreatif tetapi tidak bersifat dan mempunyai keunggulan bersaing di pasar. Hubungan inovasi dengan pasar yang didalamnya ada 5C, yaitu Competitior (pesaing), Competition (persaingan), Change of Competition (perubahan persaingan), Change Driver (penentu arah perubahan), dan Customer Behavior (perilaku konsumen). Selanjutnya adalah mampu meningkatkan nilai tambah perusahaan. Adanya nilai tambah (value added) bisa menjadi pendongkrak pertumbuhan dan perkembangan perusahaan.Faktor lainnya adalah memiliki unsur efisiensi dan efektivitas. Tanpa 2E yaitu faktor efisiensi dan faktor efektivitas dari sebuah inovasi yang ditemukan maka inovasi tersebut tidak mempunyai arti atau dampak yang berarti bagi kemajuan perusahaan. Faktor yang lain adalah harus sejalan dengan visi dan misi perusahaan. Inovasi harus sejalan dengan visi dan misi perusahaan agar tidak menyimpang dari arah pertumbuhan usaha. Lalu yang terakhir adalah perusahaan harus bisa meningkatkan 
inovasi terus menerus. Inovasi harus bisa diinovasikan lagi sehingga terjadi inovasi yang berkelanjutan hingga menumbuhkan perusahaan menjadi lebih baik dan lebih berkembang.

\section{Keunggulan Bersaing}

\section{Pengertian Keunggulan Bersaing}

Porter (1993) mendefinisikan keunggulan bersaing sebagai strategi benefit dari perusahaan yang melakukan kerjasama untuk berkompetisi lebih efektif dalam market place. Strategi harus didisain untuk mewujudkan keunggulan bersaing yang terus menerus, sehingga perusahaan dapat mendominasi pasar lama maupun pasar baru. Hal terpenting dalam mencapai kesuksesan strategi yang diterapkan adalah dengan mengidentifikasi asset perusahaan yang sesungguhnya, dalam hal ini adalah tangible dan intangible resources yang membuat organisasi itu unik.

Keunggulan bersaing menurut Jap (1991) dapat terpenuhi jika pelanggan memperoleh perbedaan yang konsisten dalam atribut yang terpenting dari produk yang dihasilkan dibandingkan pesaingnya dimana perbedaan tersebut merupakan dampak langsung dari kesenjangan / kemampuan antara produsen dan pesaingnya. Menurut Gana (2003) perusahaan yang melakukan inovasi berkelanjutan dipandang sebagai sumber keunggulan bersaing.

Barney (1991) mengutarakan empat indikator sehingga kompetensi yang dimiliki perusahaan dapat menjadi sumber keunggulan bersaing yang berkesinambungan, yakni: bernilai (valuable), merupakan kompetensi langka diantara perusahaan-perusahaan yang ada dan pesaing potensial (rare), tidak mudah ditiru (inimitability), dan tidak mudah digantikan (nonsubstitutability). Kompetensi bernilai (valuable competencies) adalah kompetensi yang menciptakan nilai bagi suatu perusahaan dengan mengeksploitasi peluang-peluang atau menetralisir ancamanancaman dalam lingkungan eksternal perusahaan. Kompetensi dikatakan bernilai ketika kompetensi tersebut menyebabkan perusahaan mampu menyusun dan mengiplementasikan strategi-strategi yang dapat meningkatkan nilai bagi pelanggan khususnya. Kompetensi langka adalah kompetensi yang dimiliki oleh sedikit, jika ada, pesaing saat ini atau potensial. Kompetensi perusahaan yang bernilai namun dimiliki oleh sebagian besar pesaing yang ada atau pesaing potensial tidak dapat menjadi sumber keunggulan bersaing yang berkesinambungan. Kompetensi dapat dikatakan sulit ditiru karena satu atau kombinasi dari tiga alasan, yaitu kemampuan perusahaan untuk memperoleh kompetensi tergantung pada kondisi historis yang unik, hubungan antara kompetensi yang dimiliki oleh perusahaan dengan keunggulan bersaing yang berkesinambungan bersifat ambigu (causally ambiguous), dan kompetensi yang menghasilkan keunggulan perusahaan tersebut bersifat kompleksitas sosial (socially complex). Kompetensi yang sulit digantikan adalah kompetensi yang tidak memiliki ekuivalen strategis. Dua sumberdaya perusahaan yang bernilai (atau dua kumpulan sumberdaya perusahaan) ekuivalen secara strategis ketika tiap sumberdaya itu dapat dieksploitasi secara terpisah untuk mengimplementasikan strategi-strategi yang sama. 
Meningkatkan Keunggulan Bersaing

Menurut Porter (2008) mekanisme yang memungkinkan perusahaan meningkatkan keunggulan bersaing. yaitu meredam fluktuasi permintaan pesaing sehingga dapat meredam fluktuasi yang timbul karena adanya pola siklus, pola musiman, dan penyebab lainnya; meningkatkan kemampuan diferensiasi pesaing; melayani segmen pasar yang kurang menarik bagi para pesaing; menjadi pelindung biaya (cost umbrella) pesaing; meningkatkan posisi tawar tenaga kerja dan pembuat undang-undang; memperkecil resiko anti-monopoli; dan meningkatkan motivasi pesaing.

\section{Dimensi Keunggulan Bersaing}

Dranove \& White dalam Diab (2014) membagi dimensi keunggulan bersaing menjadi empat, yaitu biaya, fleksibilitas (flexibility), pengantaran (delivery), dan kualitas (quality). Fokus pada pengurangan biaya adalah dimensi yang paling umum digunakan oleh organisasi, terutama di pasar dimana pelanggan sensitif terhadap harga. Menurut Tiengtavaj et al. (2017), biaya merupakan faktor yang perlu diperhatikan baik di lingkungan internal maupun eksternal. Secara khusus, bisnis dapat mengurangi biaya pengelolaan internal serta mengurangi dan memperpendek proses pengembangan dan manufaktur. Manajemen sumber daya dalam organisasi adalah teknik yang murah dan efektif untuk mencapai hal tersebut. Secara umum, sebagian besar organisasi memilih untuk memotong total biaya dengan menghilangkan biaya tetap dan menerapkan kontrol terus menerus terhadap bahan baku, mengurangi tingkat kompensasi karyawan, dan dengan mencapai tingkat produktivitas yang lebih tinggi (Moghli et al., 2012).
Fleksibilitas diartikan sebagai kemampuan organisasi untuk menyediakan variasi dan tingkat yang berbeda di pasar sasaran melalui kemampuannya untuk mengimbangi perkembangan teknologi, dan merancang produk dan layanan sesuai dengan harapan pelanggan (Russel dalam Diab ,2013). Organisasi harus dapat bekerja dengan waktu sesingkat mungkin dan memiliki fleksibilitas dalam proses produksi. Efektivitas dan efisiensi suatu organisasi dapat dicapai dengan menciptakan lingkungan yang memberi arti penting bagi kedekatan pekerjaan yang terjadi di dalam organisasi tersebut (Tiengtavaj et al., 2017). Zhang et al. (2003) dalam taksonomi, mengidentifikasi dua kelas fleksibilitas: fleksibilitas kerja adalah kemampuan dari Sistem untuk mengatasi perubahan pekerjaan yang akan diproses oleh suatu sistem, sedangkan fleksibilitas mesin adalah kemampuan suatu sistem untuk mengatasi perubahan dan gangguan pada mesin dan workstation. Di sisi lain, Gupta et al. (1996) mengklasifikasikan fleksibilitas ke dalam tiga kategori: fleksibilitas yang diperlukan (fleksibilitas mesin, fleksibilitas produk, fleksibilitas tenaga kerja, fleksibilitas penanganan material, fleksibilitas perutean, fleksibilitas volume), fleksibilitas yang memadai (fleksibilitas proses, fleksibilitas operasional, fleksibilitas program, fleksibilitas material) dan fleksibilitas kompetitif (fleksibilitas produksi, fleksibilitas ekspansi, pasar fleksibilitas).

Pengantaran (delivery) merupakan prioritas yang kompetitif karena pelanggan tertarik untuk memuaskan kebutuhan dan keinginan mereka dalam jumlah yang tepat pada waktu yang tepat. Li (2000) berpendapat bahwa kemampuan delivery adalah masalah waktu di mana ia 
mencerminkan konsep berikut: jumlah aspek operasi perusahaan; seberapa cepat suatu produk atau layanan dikirimkan ke pelanggan; seberapa andal produk atau layanan tersebut dikembangkan dan dibawa ke pasar; dan tingkat di mana perbaikan dalam produk dan proses dibuat. Bakri (2005) menyatakan kecepatan pelayanan dan respons terhadap permintaan pelanggan telah menjadi salah satu faktor persaingan antar organisasi, hal ini terkait dengan kemauan pelanggan untuk membayar biaya lebih tinggi untuk layanan atau produk yang dia butuhkan secara tepat waktu.

Kualitas adalah senjata kompetitif di pasar. Kualitas menghasilkan keunggulan bersaing dengan menyediakan produk yang memenuhi atau melampaui kebutuhan dan harapan pelanggan (Lee et al., 2000). Tiengtavaj (2017) juga menyatakan kualitas adalah faktor yang perlu merespon harapan pelanggan dengan menghasilkan produk yang lebih berharga atau menghasilkan layanan yang lebih tinggi daripada persaingan dan bertujuan untuk mendapatkan kepuasan pelanggan yang lebih tinggi yang memenuhi atau melampaui harapan. Garvin dalam Awwad et al. (2013) mengidentifikasi delapan dimensi untuk kualitas sebagai: kinerja, fitur, keandalan, kesesuaian, daya tahan, kemampuan servis, kualitas dan kualitas yang dirasakan.

\section{Hubungan Strategi Inovasi dan Keunggulan Bersaing}

Song et al. (1997) menjelaskan bahwa keunggulan bersaing suatu produk merupakan salah satu faktor penentu dari kesuksesan produk baru (hingga suatu produk inovasi harus mempunyai keunggulan dibanding dengan produk lain sejenis). Sesuai pula dengan pendapat
Cooper (2000) bahwa keunggulan produk baru sangat penting dalam lingkaran pasar global yang sangat bersaing. Keunggulan tersebut tidak lepas dari pengembangan produk inovasi yang dihasilkan sehingga akan mempunyai keunggulan dipasar yang selanjutnya akan menang dalam persaingan. Lalu menurut Wahyono (2002) menjelaskan bahwa inovasi yang berkelanjutan dalam suatu perusahaan merupakan kebutuhan dasar yang pada gilirannya akan mengarah pada terciptanya keunggulan kompetitif.

\begin{tabular}{|c|c|}
\hline $\begin{array}{ll} & \text { Strategi Inovasi } \\
\text { 1. } & \text { Orientasi } \\
\text { Kepemimpinan } \\
\text { 2. } & \text { Tipe Inovasi } \\
\text { 3. } & \text { Sumber Inovasi } \\
\text { 4. } & \text { Tingkat Investasi } \\
& \text { (Kazinguvu, 2016) }\end{array}$ & $\begin{array}{l}\quad \begin{array}{c}\text { Keunggulan } \\
\text { Bersaing }\end{array} \\
\text { 1. Cost } \\
\text { 2. Flexibility } \\
\text { 3. Delivery } \\
\text { 4. Quality } \\
\text { (Dranove \& White } \\
\text { dalam Diab, 2013) }\end{array}$ \\
\hline
\end{tabular}

Gambar 2 Hubungan Strategi dan Keunggulan Bersaing

Hal tersebut juga dikemukakan oleh Chen et al. dalam Costa et al. (2010) yang menyatakan bahwa inovasi adalah sumber utama keunggulan kompetitif dalam era ekonomi pengetahuan, karena melalui diferensiasi dibuat memungkinkan perusahaan untuk mempertahankan keunggulan mereka lebih baik. Selain itu Kuczmarski (2003) juga menyatakan bahwa untuk mencapai keunggulan bersaing, maka inovasi itu harus selalu fokus untuk menciptakan sesuatu yang baru dalam dunia.

Hubungan tersebut dapat dilihat dari dimensi-dimensi yang dimiliki. Pada studi kasus UKM kerjinan tangan di kota Bandung ini meggunakan dimensi yang dikemukakan oleh Zahra \& Das (1993) dan Dranove \& White dalam Diab (2013). Startegi inovasi memiliki dimensi yang 
terdiri dari orientasi kepemimpinan, tipe inovasi, sumber inovasi, dan tingkat investasi. Sedangkan dimensi keunggulan bersaing teridiri dari biaya, fleksibilitas, pengantaran, dan kualitas. Hal ini dapat dilihat pada gambar 2. Sehingga hipotesis yang digunakan pada penelitian ini adalah sebagai berikut:

Ho: Tidak ada pengaruh strategi inovasi terhadap keunggulan bersaing pada UMKM sektor kerajinan tangan di kota Bandung

H1: Ada pengaruh strategi inovasi terhadap keunggulan bersaing pada UMKM sektor kerajinan tangan di kota Bandung.

\section{METODE PENELITIAN}

\section{Populasi dan Metode Penarikan Sampel}

Jumlah populasi UMKM industri kreatif sektor kerajinan tangan di Kota Bandung yang terdaftar di Perindag Kota Bandung adalah sebesar 187. Penulis hanya akan mengambil sebaian kecil dari populasi mengingat banyaknya populasi UMKM kerajinan tangan di kota Bandung.

Teknik sampling yang digunakan dalam penelitian ini adalah nonprobability sampling dengan cara pengambilan sampel menggunakan quota sampling. Quota sampling menurut Indrawati (2015) adalah pegambilan anggota sampel secara convenience dari populasi yang terbatas dengan jumlah sampel telah ditentukan terlebih dahulu. Sampel yang diambil adalah UMKM dibidang kerajinan tangan (handycraft) di Kota Bandung dan jumlah sampel yang ditetapkan adalah 51 UMKM, dengan 153 responden. Dari total UMKM di bidang kerajinan tangan sebanyak 187. Menurut Sekaran (2011), sebagai aturan umum ukuran sampel antara 30 dan 500 bisa efektif tergantung pada tipe desain pengambilan sampel yang dipakai dan pertanyaan penelitian yang diteliti.

\section{Operasional Variabel}

Variabel yang digunakan dalam penelitian ini terdiri dari variabel bebas (independent variable) yaitu inovasi dan variabel terikat (dependent variable) yaitu keunggulan bersaing. Keseluruhan indikator baik itu pada variabel inovasi maupun pada variabel keunggulan bersaing diukur dengan skala ordinal.

\section{Analisis Data}

Sebelum dilakukan analisis data, terlebih dahulu harus dilakukan uji validitas dan reliabilitas terhadap alat ukur penelitian yang digunakan pada penelitian ini. Uji asumsi klasik dilakukan pada tahap awal analisis data. Hal ini dilakukan sebagai persyaratan agar data yang dikumpulkan memenuhi syarat untuk analisis regresi linear. Pengujian dilakukan dengan cara uji normalitas untuk mengetahui apakah data berdistribusi normal atau tidak. Data dikatakan berdistribusi normal jika data menyebar disekitar garis diagonal atau grafik histogram yang dibentuk dari data menunjukan pola distribusi normal. Uji linearitas digunakan untuk mengkonfirmasi apakah sifat linear antara dua variabel yang diidenfitikasi secara teori sesuai atau tidak dengan hasil observasi yang telah dilakukan. Pengujian pada penelitian ini menggunakan Test for Linearity dengan taraf signifikansi 0,05 . Dua variabel dikatakan mempunyai hubungan linear apabila signifikansi (linearity) kurang dari 0,05. Pengujian awal selanjutnya adalah uji heteroskedastisitas yang bertujuan untuk menguji apakah dalam model regresi terjadi ketidaksamaan varians residual atau suatu pengamatan ke 
pengamatan yang lain adalah tetap, maka disebut homoskedasititas atau tidak terjadi heteroskedastisitas.

Teknik analisis deskriptif yang digunakan pada penelitian ini antara lain adalah distribusi frekuensi, mean dan standar deviasi. Frekuensi mengacu pada berapa kali suatu fenomena terjadi, yang mana presentase dan presentase kumulatif jumlah kejadiannya dapat dihitung dengan mudah (Sekaran, 2003). Mean atau dikenal dengan rata-rata hitung (average) digunakan untuk memberikan gambaran umum mengenai data tanpa membanjiri seseorang dengan data yang tidak perlu. Sementara standar deviasi adalah ukuran untuk data berskala interval dan rasio yang memberikan indeks penyebaran distribusi atau variabilitasa dalam data. Standar deviasi yang tidak lebih dari 20\% dari mean menunjukkan adanya variasi yang rendah.

Analisis regresi linier sederhana dilakukan setelah hasil dari pengujian awal menyatakan bahwa data yang digunakan memenuhi syarat dilakukannya regresi linear. Menurut Sunyoto (2011) ananlisis regresi adalah suatu analisis yang mengukur pengaruh antara variabel bebas terhadap variabel terikat. Jika pengukuran pengaruh ini melibatkan satu variabel bebas (X) dan variabel terikat (Y) dinamakan analisis regresi linear sederhana. Analisis ini digunakan untuk mengukur perubahan variabel terikat berdasarkan perubahanperubahan variabel bebas.

Salah satu indikator yang harus diperhatikan dari regresi linier adalah nilai koefisien determinasi yang bernilai 0 hingga 1. Nilai yang kecil menunjukan kemampuan variabel-variabel independen dalam mempengaruhi variabel dependen sangat terbatas. Nilai yang mendekati satu berarti variabel-variabel independen memberikan hampir semua informasi yang dibutuhkan untuk memprediksi variabel independen.

$$
\text { Pengujuian hipotesis dilakukan }
$$
untuk pengambilan kesimpulan. Uji statistik F dan uji statistic t-student dilakukan pada tahap ini. Pada penelitian ini, penulis menggunakan $\geq 5 \%$ atau tingkat kepercayaan 95\%. Jika signifikansi < 0,05 maka Ho ditolak, dan jika signifikansi > 0,05 maka $\mathrm{H}_{0}$ tidak cukup bukti untuk menolak $\mathrm{H}_{0}$.

Tabel 1 Demografi Responden

\begin{tabular}{lcc}
\hline \multicolumn{1}{c}{ Kategori } & Frekuensi & $\begin{array}{c}\text { Persentase } \\
(\%)\end{array}$ \\
\hline Jenis Kelamin & & \\
Pria & 57 & 37 \\
Wanita & 96 & 63 \\
Usia & & \\
20-35 tahun & 81 & 53 \\
36-50 tahun & 51 & 33 \\
51-65 tahun & 21 & 14 \\
Pendidikan & & \\
Terakhir & & \\
SMA/Sederajat & 42 & 27 \\
D1/D2/D3 & 18 & 12 \\
D4/S1 & 87 & 57 \\
S2/S3 & 6 & 4 \\
Jumlah Karyawan & & \\
1-5 orang & 93 & 60 \\
6-10 orang & 42 & 27 \\
11-20 orang & 18 & 13 \\
Lama Berdirinya & & \\
Usaha & & \\
1-5 tahun & 93 & 60 \\
6-10 tahun & 36 & 24 \\
11-20 tahun & 6 & 4 \\
> 20 tahun & 18 & 12 \\
Omzet per Tahun & & \\
Rp 50-300 juta & 81 & 53 \\
Rp 300-2.500 juta & 63 & 41 \\
Rp 2.500-50.000 & 9 & 6 \\
juta & & \\
\hline
\end{tabular}

\section{HASIL PENELITIAN}

\section{Deskripsi Responden}

Penyebaran kuesioner dilakukan kepada 51 organisasi (UMKM) kerajinan tangan di kota Bandung, dan 153 sebagai responden yang terdiri dari pelaku usaha 
(manajer/owner/karyawan). Demografi responden secara lengkap dapat dilihat pada tabel 1 .

\section{Pengujian Validitas dan Reliabilitas}

Pengukuran validitas dan reliabilitas ini diujikan pada semua responden, yaitu 153 responden, baik itu untuk variabel strategi inovasi maupun keunggulan bersaing. Berdasarkan hasil pengolahan dengan menggunakan SPSS, 17 pernyataan dinyatakan valid, karena pada kolom corrected item-total correlation, menunjukkan angka $\geq 0,300$. Selanjutnya adalah uji validitas dari variabel $\mathrm{Y}$ atau keunggulan bersaing menunjukan bahwa sebanyak 13 pernyataan dinyatakan valid, karena pada kolom corrected item-total correlation, menunjukkan angka $\geq 0,300$.

Hasil reliabilitas untuk variabel inovasi dapat dilihat dari cronbach's alpha yang menunjukkan hasil 0,867. Nilai tersebut lebih dari 0,600 , sehingga indikatorindikator strategi inovasi tersebut dapat dikatakan reliabel atau memiliki reliabilitas yang baik. Hasil dari cronbach's alpha untuk variabel keunggulan bersaing yaitu 0,829, nilai tersebut lebih besar dari 0,600, sehingga indikator-indikator keunggulan bersaing tersebut memiliki reliablilitas yang cukup tinggi atau dapat dikatakan bahwa indikator variabel keunggulan bersaing memiliki reliabilitas yang baik.

\section{Pengujian Awal}

Uji Normalitas yang digunakan dalam penelitian ini adalah dengan metode Grafik normal Probability plot (P-Plot). Hasil uji normalitas antara variabel strategi inovasi dan keunggulan bersaing dapat dilihat pada gambar 4 .

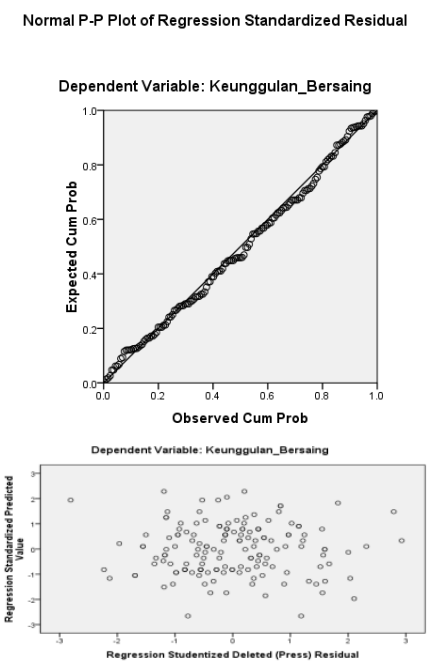

(a)

(b)

Gambar 3 (a) Grafik normal probability plot, (b) Scatterplot uji heteroskedastisitas

Hasil kurva normal P-Plot di atas membuktikan bahwa titik-titik pada grafik berhimpit dan mengikuti garis diagonalnya. Titik-titik (sebaran data) mendekati atau berkonsentrasi di sekitar uji yang mengarah ke pojok kanan atas. Tidak ada data yang letaknya jauh dari garis sebaran data. Hal ini berarti sebaran data membentuk distribusi normal. Oleh karena itu dapat disimpulkan bahwa model regresi antara strategi inovasi dan keunggulan bersaing dalam penelitian ini berdistribusi normal. Sedangkan untuk hasil uji heteroskedastitas dapat dilihat pada gambar 4(b). Kurva scatterplot di atas memperlihatkan semua titik tidak membentuk suatu pola dan menyebar di atas dan dibawah angka 0 pada sumbu Y. Maka dapat diambil kesimpulan bahwa pada model ini tidak terjadi heterokedastisitas.

Pengujian liniearitas pada penelitian ini dilakukan dengan membandingkan ratarata kedua variabel. Pada pengujian ini, kedua variabel dikatakan mempunyai hubungan yang linear jika memiliki signifikansi (linearity) kurang dari 0,05. Pada penelitian ini dapat dilihat linearity variabel strategi inovasi dan keunggulan 
bersaing adalah 0.000. Dengan demilian, maka terbukti bahwa hubungan pada pasangan variabel strategi inovasi dan keunggulan bersaing memenuhi asumsi linearitas. Hal ini juga menggambarkan bahwa pertambahan nilai dari satu variabel diikuti oleh pertambahan nilai dari variabel lainnya.

\section{Analisis Deskriptif Strategi Inovasi}

Strategi inovasi UMKM kerajinan tangan berada dalam kategori tinggi jika mengacu pada nilai interval rata-rata untuk setiap indikator. Berdasarkan hasil dari SPSS, dimensi variabel inovasi mempunyai nilai mean 3,41 yang berarti strategi inovasi yang dihasilkan oleh pelaku usaha UMKM Kerajinan Tangan di Kota Bandung tergolong pada kategori “Tinggi”. Dimensi yang memiliki mean terbesar adalah Orientasi Kepemimpinan 3,51 yang tergolong tinggi. Sedangkan dimensi yang memiliki mean terendah adalah Sumber Inovasi, yaitu 3.29 yang tergolong pada kategori "Cukup Tinggi”. Dimensi tingkat investasi juga termasuk dalam kategori "Cukup Tinggi" yaitu 3,28. Nilai standard deviation dari variabel ini berada di bawah $20 \%$ dari rata-rata, yaitu sebesar 14,9\%, yang menunjukan bahwa jawaban responden memiliki tingkat variasi yang rendah atau rata-rata yang sama.

\section{Analisis Deskriptif Keunggulan Bersaing}

Berdasarkan hasil analisis mean dengan menggunakan SPSS, secara umum keunggulan bersaing memiliki mean sebesar 3,55. Angka tersebut menunjukan bahwa keunggulan bersaing pada UMKM kerajinan tangan di kota Bandung termasuk dalam kategori "Tinggi". Dimensi dengan nilai mean tertinggi adalah dimensi Quality yaitu sebesar 3,66 dan termasuk dalam kategori
"Tinggi". Sedangkan dimensi dengan mean terendah yaitu dimensi Cost atau sebesar 3,3, yang termasuk dalam kategori "Cukup Tinggi”. Secara keseluruhan, nilai standar deviasi pada dimensi tingkat investasi adalah sebesar 0.41354 atau $11,6 \%$. Hal ini berarti responden memiliki variasi jawaban yang rendah.

\section{Analisis Korelasi}

Metode yang digunakan untuk analisis korelasi antara variabel strategi inovasi dan keunggulan bersaing pada penelitian ini adalah korelasi Pearson. Hasil output dari analisis ini ditunjukan oleh tabel 2. nilai korelasi antara variabel strategi inovasi dengan keunggulan bersaing adalah sebesar 0.734. Angka ini terdapat pada interval 0,60-0,799 yang berarti strategi inovasi dengan keunggulan bersaing memiliki hubungan positif yang kuat. Nilai korelasi pearson pada tabel diatas menunjukkan nilai positif, maka hubungan antara strategi inovasi dengan keunggulan bersaing adalah searah, yang berarti jika strategi inovasi meningkat maka akan diikuti oleh peningkatan keunggulan bersaing. Untuk mengetahui apakah hubungan antara strategi inovasi (x) dan keunggulan bersaing (y) signifikan atau tidak, maka dapat dilakukan uji signifikansi dengan uji hipotesis. nilai signifikasi hasil korelasi antara strategi inovasi denga keunggulan bersaing menunjukkan angka 0,000. Tingkat signifikansi dapat digunakan untuk menguji apakah angka korelasi yang diperoleh benar-benar signifikan dan dapat digunakan untuk menjelaska hubungan kedua variabel tersebut. Menurut Sugiama (2008), jika sig <0.05 maka korelasi tersebut sigifikan. Sebaliknya korelasi tidak signifikan jika sig >0.05. Maka, dapat disimpulkan inovasi memiliki hubungan 
yang signifikan dengan keunggulan bersaing.

Tabel 2 Hasil Analisis Korelasi

\begin{tabular}{|ll|c|c|}
\hline & & $\begin{array}{c}\text { Strategi } \\
\text { Inovasi }\end{array}$ & $\begin{array}{c}\text { Keunggulan } \\
\text { Bersaing }\end{array}$ \\
\hline $\begin{array}{l}\text { Strategi } \\
\text { Inovasi }\end{array}$ & $\begin{array}{l}\text { Pearson } \\
\text { Correlation }\end{array}$ & 1 & $.734^{* *}$ \\
& Sig. (2-tailed) & & .000 \\
& $\mathrm{~N}$ & 153 & 153 \\
\hline $\begin{array}{l}\text { Keunggulan } \\
\text { Bersaing }\end{array}$ & Pearson & $.734^{* *}$ & 1 \\
& Correlation & .000 & \\
& $\mathrm{~N}$ & 153 & 153 \\
\hline
\end{tabular}

**. Correlation is significant at the 0.01 level (2-tailed).

Tabel 3 Hasil Analisis Regresi Linear

\begin{tabular}{|c|c|c|c|c|c|c|c|}
\hline \multirow[t]{2}{*}{ Model } & \multicolumn{2}{|c|}{$\begin{array}{l}\text { Unstandar } \\
\text { dized } \\
\text { Coefficien } \\
\text { ts }\end{array}$} & \multirow[t]{2}{*}{\begin{tabular}{|c|} 
Standar \\
dized \\
Coeffici \\
ents
\end{tabular}} & \multirow[t]{2}{*}{$\mathrm{t}$} & \multirow[t]{2}{*}{ Sig. } & \multicolumn{2}{|c|}{$\begin{array}{c}\text { Collinea } \\
\text { rity } \\
\text { Statistic } \\
\text { s }\end{array}$} \\
\hline & B & $\begin{array}{c}\text { Std. } \\
\text { Erro } \\
r\end{array}$ & & & & \begin{tabular}{|l|} 
Tol \\
era \\
nce
\end{tabular} & $\begin{array}{l}\text { VI } \\
\text { F }\end{array}$ \\
\hline (Constant) & $\begin{array}{l}19.9 \\
03\end{array}$ & $\begin{array}{l}2.00 \\
9\end{array}$ & & 9.908 & $\begin{array}{l}.00 \\
0\end{array}$ & & \\
\hline $\begin{array}{l}\text { Strategi_I } \\
\text { novasi }\end{array}$ & .453 & .034 & .734 & $\begin{array}{l}13.26 \\
3\end{array}$ & $\begin{array}{l}.00 \\
0\end{array}$ & $\begin{array}{l}1.0 \\
00\end{array}$ & $\begin{array}{l}1.0 \\
00\end{array}$ \\
\hline
\end{tabular}

a. Dependent Variable: Keunggulan_Bersaing

\section{Analisis Regresi Linear}

Analisis regresi linear digunakan untuk memprediksi bagaimana perubahan nilai strategi inovasi jika nilai keunggulan bersaing pada UMKM kerajinan tangan di Kota Bandung dinaikkan atau diturunkan. Hasil dari analisis regresi linear dapat dilihat pada tabel 3. Berdasarkan tabel tersebut dapat diketahui konstanta (a) bernilai 19,903 dengan koefisien regresi (b) sebesar 0,453. Konstanta sebesar 19,903 dapat diartikan jika inovasi bernilai $(X=0)$ maka keunggulan bersaing yang tercapai hanya sebesar 19,903. Strategi inovasi memiliki nilai koefisien regresi linear sebesar 0,453. Ini berarti setiap penambahan satu angka strategi inovasi dengan koefisien bernilai positif, maka keunggulan bersaing akan mengalami peningkatan sebear 0,453.

Hasil koefisien determinasi antara strategi inovasi terhadap keunggulan bersaing menunjukan nilai 0,538 , seperti terlihat pada tabel 4. Dengan demikian inovasi mampu mempengaruhi keunggulan bersaing sebesar $53,8 \%$. Sementara sisanya $46,2 \%$ dipengaruhi faktor-faktor lain yang tidak dijelaskan dalam penelitian ini.

Tabel 4 Hasil Koefisien Determinasi

\begin{tabular}{|c|c|c|c|c|c|c|c|c|}
\hline \multirow[b]{2}{*}{$\mathrm{R}$} & \multirow[b]{2}{*}{$\begin{array}{c}\mathrm{R} \\
\text { Squa } \\
\text { re }\end{array}$} & \multirow[b]{2}{*}{$\begin{array}{c}\text { Adju } \\
\text { sted } \\
\text { R } \\
\text { Squa } \\
\text { re }\end{array}$} & \multirow[b]{2}{*}{$\begin{array}{l}\text { Std. } \\
\text { Error } \\
\text { of the } \\
\text { Estim } \\
\text { ate }\end{array}$} & \multicolumn{5}{|c|}{ Change Statistics } \\
\hline & & & & $\begin{array}{c}\mathrm{R} \\
\text { Squa } \\
\text { re } \\
\text { Chan } \\
\text { ge }\end{array}$ & $\begin{array}{c}\mathrm{F} \\
\text { Change }\end{array}$ & df1 & df2 & $\begin{array}{c}\text { Sig. } \\
\text { F } \\
\text { Cha } \\
\text { nge }\end{array}$ \\
\hline .734 & .538 & .535 & 3.665 & .538 & 175.907 & 1 & 151 & .000 \\
\hline
\end{tabular}

Tabel 5 Hasil Uji -F

\begin{tabular}{|l|c|c|c|c|c|}
\hline \multicolumn{1}{|c|}{ Model } & $\begin{array}{c}\text { Sum of } \\
\text { Squares }\end{array}$ & df & $\begin{array}{c}\text { Mean } \\
\text { Square }\end{array}$ & F & Sig. \\
\hline Regression & 2363.884 & 1 & 2363.88 & 175.90 & .00 \\
Residual & 2029.175 & 151 & 13.43 & & \\
Total & 4393.059 & 152 & & & \\
\hline
\end{tabular}

\section{Uji Hipotesis}

Uji $-F$

Nilai $F$ hitung dapat dilihat pada regresi dan dilihat $\mathrm{F}$ tabel didapat melalui signifikansi. $\alpha: 0,05$ dengan df1 $: \mathrm{k}$ dan $\mathrm{df} 2$ : n-1-k. Dari tabel 5 dapat diketahui bahwa nilai $F$ hitung adalah 175.907. Sementara itu dengan df1 : 1 dan df2 : 153-1-1 = 151, maka didapat $F$ tabel 3,90. Dengan demikian, nilai F hitung lebih besar dibandig nilai $\mathrm{F}$ tabel. Maka model regresi dalam penelitian ini dapat diterima. Hal ini dapat 
disimpulkan bahwa Ho ditolak dan H1 diterima. Ini menunjukkan adanya pengaruh yang signifikan antara strategi inovasi terhadap keunggulan bersaing.

\section{$U j i-t$}

Berdasarkan hasil uji -t yang dapat diliat pada tabel 6 , diperoleh nilai t hitung sebesar 9,908, sementara untuk $t$ tabel dengan signifikansi $\alpha: 0,05$, dan df sebesar 152 didapat $t$ tabel sebesar 1,65. Berdasarkan data tersebut, nilai $\mathrm{t}$ hitung lebih besar dibandingkan dengan $\mathrm{t}$ tabel, dan dapat disimpulkan bahwa H1 diterima dan Ho ditolak. Hal ini juga menunjukkan adanya pengaruh positif dan signifikan antra strategi inovasi dengan keunggulan bersaing pada UMKM kerajinan tangan di kota Bandung. Nilai probabilitas yang ditampilkan pada tabel menunjukkan angka yang lebih kecil dari 0,000, yaitu 0,05. Dengan demikan, model regresi dapat digunakan untuk memprediksi keunggulan bersaing UMKM kerajinan tangan di kota Bandung.

\section{Tabel 6 Hasil Uji -t}

\begin{tabular}{|l|c|c|}
\hline \multicolumn{1}{|c|}{ Model } & $\mathrm{t}$ & \\
\hline (Constant) & 9.908 & .000 \\
Strategi Inovasi & 13.263 & .000 \\
\hline
\end{tabular}

\section{KESIMPULAN}

Berdasarkan hasil pengumpulan dan pengolahan data, dan pembahasan yang telah dilakukan, maka dapat disimpulkan bahwa strategi inovasi UMKM kerajinan tangan di kota Bandung termasuk dalam kategori tinggi, yang diukur melalui empat dimensi, yaitu orientasi kepemimpinan, tipe inovasi, sumber inovasi, dan tingkat investasi. Dimensi orientasi kepemimpinan memiliki mean tertinggi, sedangkan dimensi yang memiliki mean terendah adalah tingkat investasi. Indikator dengan mean tertinggi yang berada dalam kategori tinggi terdapat pada dimensi tipe inovasi yang ditunjukkan oleh indikator perusahaan menghasilkan produk dengan beragam jenis/desain. Sedangkan indikator dengan mean terendah ditunjukkan oleh pernyataan perusahaan menggunakan alat-alat produksi yang berteknologi dalam menjalankan usaha, yang termasuk dalam dimensi tipe inovasi.

Keunggulan bersaing UMKM kerajinan tangan di kota Bandung berada pada kategori tinggi, yang diukur oleh empat dimensi, yaitu cost, flexibility, delivery, dan quality. Dimensi yang memiliki mean tertinggi yaitu dimensi Quality. Sedangkan dimensi yang memiliki mean terendah adalah dimensi Cost. Hal ini menunjukkan UMKM kerajinan tangan di kota Bandung menyadari akan pentingnya kualitas. Indikator dengan nilai mean terendah yang berada pada kategori cukup tinggi terdapat pada dimensi flexibility yang ditunjukkan dengan indikator penyesuaian UMKM dalam teknologi yang ada. Sedangkan indikator dengan nilai mean tertinggi yang berada pada kategori tinggi terdapat pada dimensi quality yang ditunjukkan oleh indikator kualitas layanan yang selalu ditingkatkan.

Hasil dari penelitian ini menunjukan adanya hubungan yang positif dan kuat antara variabel strategi inovasi dengan keunggulan bersaing. Besarnya pengaruh strategi inovasi terhadap keunggulan bersaing pada UMKM kerajinan tangan di kota Bandung yaitu sebesar 53,8\%. Sementara sisanya, 46,2\% dipengaruhi oleh faktor-faktor lain yang tidak dijelaskan dalam penelitian ini. Inovasi juga 
berpegaruh secara signifikan terhadap keunggulan bersaing.

Saran yang dapat diberikan untuk penelitian selanjutnya yaitu diharapkan dapat menggunakan variabel bebas lainnya seperti praktek total quality management, implementasi system ERP, Branding, Sumberdaya Perusahaan, Kemampuan Manajemen, Moral Awareness, atau knowledge transfer.

\section{DAFTAR PUSTAKA}

Alstermark, L., \& Hegefjärd, S. (2006). Espoused Corporate and Business Level Strategies An Analysis of Annual Reports in the Heavy Electrical Engineering Linköping university.

Anatan, L., \& Ellitan, L. (2009). Manajemen Inovasi (Transformasi Menuju Organisasi Kelas Dunia). Bandung: CV. Alfabeta.

Awwad, A. S., \& Adel A. Al Khattab, J. R. (2013). Competitive Priorities and Competitive Advantage in Jordanian Manufacturing. Journal of Service Science and Management, 69-79.

Bakri, T. (2005). The Marketing of Health Services. Amman - Jordan: Alyazoori for Puplishers.

Barney, J. B. (1991). Firm resources and sustained competitive advantage. Journal of Management, 17, 99-120.

Briones, J. (2014). Using Value-Based Innovation for New Product Intorductions. from http://www.slideshare.net/Brioneja/v alue-in-use-analysis-and-strategyfor-product-introductions-jose-abriones-product-camp-autin-tx$\underline{03272010 \mathrm{a}}$

Charan, R., \& Lafley, A. G. (2008). Why Innovation Matters Fast Company.
Retrieved Mei 30, 2017, from http://www.fastcompany.com/87279

8/why-innovation-matters

Cooper , R. G. (2000). Product Inovation and Technology Strategy. Journal Research Technology Management, $38-41$.

Costa, M. d. P. B., \& Cabral, J. E. d. O. (2010). The Relationship Knowledge, Learning, Innovation and Competitive Advantages: A Conceptual Model By and (Embrapa). The International Journal of Technology, Knowledge and Society.

Dhewanto, W., Indradewa, R., Ulfa, W. N., Rahmawati, S., Yoshanti, G., \& Lumanga, C. Z. (2015). Manajemen Inovasi untuk Usaha Kecil dan Mikro. Bandung: ALFABETA.

Diab, S. M. (2014). Using the Competitive Dimensions to Achieve Competitive Advantage: A Study on Jordanian Private Hospitals. International Journal of Academic Research in Business and Social Sciences, 4.

Gana, F. (2003). Inovasi Organisasi Sebagai Basis Daya Saing Bisnis. Usahawan, 10, 9-20.

Ghozali, I. (2011). Aplikasi Analisis Multivariate dengan Program IBM SPSS 19. Semarang: Universitas Dipenogoro.

Gupta, Y., \& Somers, T. (1996). Business Strategy, Manufacturing Flexibility, and Organisational Performance Relationships: A Path Analysis Approach. Production and Operations Management, 5, 204233.

Hadjimanolis, A., \& Dickson, K. (2000). Innovation Strategies of SMEs in Cyprus, A Small Developing 
Country. International Small Business Journal, 18(2), 62-79.

Han, J. K., Kim, N., \& Srivastava, R. K. (1998). Market Orientation and Organizational Performance: Is Innovation a Missing Link? Journal of Marketing, 62.

Hendro. (2011). Dasar-dasar Kewirausahaan Panduan bagi Mahasiswa untuk Mengenai, Memahami, dan Memasuki Dunia Bisnis. Jakarta: Erlangga.

Hittmár, Š., Varmus, M., \& Lendel, V. (2014). Proposal of model for effective implementation of innovation strategy to business. Procedia - Social and Behavioral Sciences, 109, 1194 - 1198.

Hurley, R. F., \& Hult, G. T. (1998). Innovation, Market Orientation, and Organizational Learning: An Integration and Empirical Examination. Journal of Marketing .

Indrawati. (2015). Metode Penelitian Manajemen dan Bisnis Konvergensi Teknologi KOmunikasi dan Informasi. Bandung: PT. Refika Aditama.

Jap, S. D. (1991). Pie-expansion Efforts: Collaboration Process in BuyerSupplier Relationship. Journal of Marketing Research, 36(4), 461-475.

Kuczmarski, T. D. (2003). What is innovation? And why aren't companies doing more of it? Journal of Consumer Marketing, 20, 536541.

Larsen, P., \& Lewis, A. (2007). How Award Winning SMEs The Barrires to Innovation. Journal of Creativity and Innovation Management, 141-151.

Lee, C., \& Zhou, X. (2000). Quality Management and Manu- facturing
Strategies in China. International Journal of Quality and Reliability Management, 17(8), 876-898.

Li, L. (2000). Manufacturing Capability Development in a Changing Business Environment. Industrial Management and Data Systems, 100, 261- 270.

Martim de Conto, S., Junior, J. A. V. A., \& Vaccaro, G. L. R. (2016). Innovation as a Competitive Advantage Issue: A Cooperative Study on an Organic Juice and Wine Producer. Gest. Prod, 23(2), 397-407.

Moghli, A., Azmi, A., Al Abdallah, G. M., \& Al Muala, A. (2012). Impact of Innovation on Realizing Competitive Advantage in Banking Sector in Jordan. American Academic \& Scholarly Research Journal, 4.

Muthami Kising, T. u., Namusonge, G. S., \& Mwirigi, F. M. (2016). The Role of Organizational Innovation in Sustainable Competitive Advantage in Universities in Kenya. The International Journal of Social Science and HUmanities Invention, 3(9), 2762-2768.

OECD. (2005). Oslo Manual: Guidelines for Collecting and Interpreting Innovation Data. Paris: OECD Publishing \& Eurostat.

Pearce, J., \& Robinson, R. (2013). Strategic Management Planning for Domestic \& Global Competition. London: McGraw-Hill Education.

Perwiranegara, A. H. (2015). Pengaruh Orientasi Kepemimpinan Pasar dan Strategi Inovasi terhadap Kinerja UKM (Studi pada UKM Kerajinan Bubut Kayu Kota Blitar). Jurnal Aplikasi Manajemen, 13(1), 77-89.

Porter, M. E. (1993). Keunggulan Bersaing : 
Menciptakan dan Mempertahankan

Kinerja Unggul. Jakarta: Erlangga.

Roberts, P., \& Amit, R. (2003). The dynamic of innovative activity and competitive advantage : The case of Australian retail banking, 1981 to 1995. Organization Science, 14(2), 107-122.

Rosli, \& Sidek. (2013). The impact of Innovationon the Performance of Small and Medium Manufacturing Enterprises:Evidence from Malaysia. Entrepreneurship Vision 2020: Innovation, Development Sustainability, and Economic Growth, 794-809.

Sekaran, U. (2003). Metodologi Penelitian untuk Bisnis. Jakarta: Salemba Empat.

Sekaran, U. (2011). Research Methods for Business. Jakarta: Salemba Empat.

Song, X. M., \& Parry, M. E. (1997). The Determinants of Japanese New Product Successes. Journal of Marketing Research, 64-76.

Sugiama, A. G. (2008). Metode Riset Bisnis dan Manajemen. Bandung: Guardaya Intimarta.

Sugiyono. (2013). Metode Penelitian Kuantitatif, Kulaitatif, dan $R \& D$. Bandung: Alfabeta.

Sukmadi. (2016). Inovasi \& Kewirausahaan. Bandung: Humaniora Utama Press.

Sunyoto, D. (2011). Analisis Regresi dan Uji Hipotesis. Yogyakarta: CAPS.

Tiengtavaj, S. T. P., \& FongsuwanKing, W. (2017). Ensuring Competitive Advantage Through Innovationcapability And Clustering In The Thai Automotiveparts Molding Industry: A Sem Approach Mongkut's Institute Of Technology
Ladkrabang (Kmitl), Faculty Of Administrative and Management. Thailand Management and Production Engineering Review, 8, 89-100.

Wahyono. (2002). Orientasi Pasar dan Inovasi: Pengaruhnya Terhadap Kinerja Pemasaran. Jurnal Sains Pemasaran Indonesia, 1.

Zahra, S. A., \& Das, S. R. (1993). Innovation Strategy and Financial Performance in Manufacturing Companies: An Empirical Study. Production and Operations Management, 2, 15-37.

Zhang, Q., Vonderembse, M., \& Lim, J. (2003). Manufacturing Flexibility: Defining and Analysing Relationships among Competence, Capability, and Customer Satisfaction. Journal of Operations Management, 21, 173-191. 